\title{
RBE on a new manuscript submission and review platform
}

\author{
Alcimar B. Soares, $\mathrm{PhD}$ \\ Editor-in-Chief
}

We are pleased to announce that our ScholarOne ${ }^{\mathrm{TM}}$ Manuscripts submission platform is now open. New submissions should be made at https://mc04.manuscriptcentral.com/reng-scielo.

In order to access the new system, you must be registered in to Research on Biomedical Engineering ScholarOne submission site - the user ID and password used in the previous system will not work. If you are not already registered, you can do so by clicking on the "New User" / "Register here" on the login screen and following the on-screen instructions. Once registered, you can login to submit your manuscript, view status, reviews, resubmit new versions etc.

If you have trouble finding your manuscripts or have other problems with your account, please contact the journal's editorial office.

As usual, before submitting a new manuscript, make sure you have all the documents required for submission, as described in our "Instructions to Authors" (http://www.rbejournal.org/authors).

To submit a new manuscript, go to the "Author Center", and click on "Click here" (Author Resources towards the bottom of the page), and then follow the on-screen instructions. There are up to 7 steps for you to follow to submit your manuscript. You move from one step to the next by clicking on the "Save and Continue" button on each screen or back to the previous screen by clicking on the "Previous" button. Note that if you click on the "Back" or "Forward" buttons on your browser, the information you have entered will not be saved.

To return to the submission process at a later date, you can click on the manuscript title in the "Unsubmitted Manuscripts" section in your "Author Center".

Please note that articles submitted before this move will remain in our previous system (Submit CuboMultimidia $^{\circledR}$ ) until the peer-review process is complete - http://rbeb.submitcentral.com.br/. 
